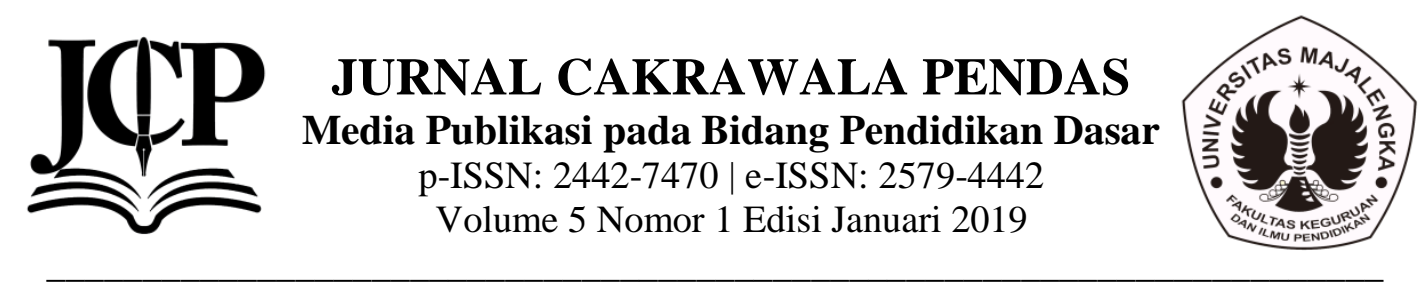

\title{
PENERAPAN MODEL CREATIVE PROBLEM SOLVING UNTUK MENINGKATKAN HASIL BELAJAR SISWA PADA PEMBELAJARAN ILMU PENGETAHUAN ALAM DI SEKOLAH DASAR
}

\author{
Yuyu Yuliati ${ }^{1}$, Intan Lestari ${ }^{2}$ \\ yuyuliati74@gmail.com \\ Universitas Majalengka
}

\begin{abstract}
ABSTRAK
Penelitian ini dilatarbelakangi masih rendahnya hasil belajar siswa pada pembelajaran Ilmu Pengetahuan Alam. Penelitian ini bertujuan untuk meningkatkan hasil belajar siswa di kelas V Sekolah Dasar Negeri Karamat 1 dengan menerapkan model pembelajaran creative problem solving (CPS). Metode Penelitian yang digunakan peneliti adalah penelitian tindakan kelas yang bekerjasama dengan guru kelas V SD Negeri Karamat 1, dengan jumlah siswa kelas V sebanyak 20 siswa terdiri dari 10 siswa laki-laki dan 10 siswa perempuan. Penelitian ini berlangsung dalam 3 siklus, setiap siklus terdiri dari 3 tindakan. Teknik yang digunakan dalam pengumpulan data yaitu observasi, tes, wawancara, dokumentasi. Hasil penelitian menunjukan bahwa menerapkan model pembelajaran Creative Problem Solving (CPS) dapat meningkatkan hasil belajar siswa pada pembelajaran IPA di kelas V SD Negeri Karamat 1. Hal tersebut di buktikan dengan data hasil pembelajaran. Pada siklus I nilai rata-rata kelas mencapai 65,08 jika dilihat dari ketuntasan belajar siswa 8 siswa (40\%) yang telah mencapai nilai KKM, sedangkan 12 siswa (60\%) masih dibawah KKM. Pada siklus II nilai rata-rata kelas mencapai 66,50 dilihat dari 11 siswa (55\%) telah mencapai nilai KKM, sedangkan 9 siswa (45\%) masih dibawah KKM. Pada siklus III dengan nilai ratarata mencapai 80,0 dilihat dari 17 siswa (85\%) telah mencapai nilai KKM, sedangkan 3 siswa (15\%) masih dibawah KKM, dengan demikian dapat disimpulkan bahwa penerapan model pembelajaran creative problem solving (CPS) dapat meningkatkan hasil belajar siswa pada pembelajaran IPA di kelas V SD Negeri Karamat 1.
\end{abstract}

Kata Kunci : creative problem solving (CPS), hasil belajar, pembelajaran IPA 


\section{Pendahuluan}

Pendidikan pada abad-21 menekankan pada pembelajaran yang memungkinkan siswa untuk mengembangkan rasa ingin tahunya, mengajarkan keterampilanketerampilan yang bermanfaat untuk kehidupan siswa di masa depan dan memungkinkan siswa untuk bekerja secara kolaboratif dalam memecahkan permasalahan. Ilmu Pengetahuan Alam merupakan ilmu dasar yang memegang peranan penting dalam perkembangan IPTEK. Dengan demikian, melalui pembelajaran siswa diharapkan memiliki berbagai keterampilan seperti keterampilan daya cipta dan inovasi, berpikir kritis dan pemecahan masalah, komunikasi, dan kerjasama. Sejalan dengan hal tersebut, pembelajaran Ilmu Pengetahuan Alam di sekolah Dasar bertujuan agar siswa memiliki pengetahuan dan keterampilan berpikir kritis dalam menyelesaikan permasalahan sains dan lingkungan. Berdasarkan hal tersebut, pembelajaran Ilmu Pengetahuan Alam di sekolah dasar hendaknya mengarahkan siswa mampu tampil kreatif dalam memecahkan berbagai permasalahan kehidupan sehari-hari melalui pemberian pengalaman langsung.

Faktanya yang terjadi di lapangan pembelajaran Ilmu Pengetahuan Alam masih terbilang belum optimal dalam mengembangkan keterampilan berpikir (Yuliati, 2016). Selain itu pembelajaran Ilmu Pengetahuan Alam juga masih belum optimal dalam mengembangkan kemampuan pemecahan masalah, sehingga kemampuan siswa dalam menyelesaikan masalah pada pembelajaran Ilmu pengetahuan alam tergolong rendah (Prastiwi, 2018). Hal tersebut membuat siswa kurang memahami materi yang disampaikan guru, selain itu siswa juga kurang termotivasi dan kurang fokus dalam kegiatan pembelajarannya sehingga membuat hasil belajar siswa kurang dari KKM. Hamdu, G \& Agustina, L (2011) menjelaskan bahwa terdapat pengaruh motivasi belajar terhadap prestasi belajar siswa pada mata pelajaran Ilmu Pengetahuan Alam. Dengan demikian guru selayaknya berupaya untuk meningkatkan hasil belajar siswa melalui berbagai kegiatan pembelajaran yang memungkinkan siswa untuk dapat mengembangkan kemampuan berpikir dan memecahkan masalah dalam situasi belajar yang menyenangkan.
Berdasarkan hasil observasi dan wawancara langsung dalam pembelajaran Ilmu Pengetahuan Alam di kelas V SDN Karamat I Kecamatan Palasah Kabupaten Majalengka, hasil belajar siswa belum memenuhi KKM. Terdapat 3 siswa atau 15\% yang berhasil mencapai kriteria ketuntasan minimal dan 17 siswa atau 85\% yang belum mencapai kriteria ketuntasan minimal, dimana KKM untuk mata pelajaran Ilmu Pengetahuan Alam adalah 75. Mengingat masih begitu rendahnya jumlah siswa yang berhasil mencapai kriteria ketuntasan minimal maka penerapan model pembelajaran inovatif dapat menjadi salah satu pilihan. Hal ini karena mata pelajaran Ilmu pengetahuan alam akan lebih mudah difahami siswa dengan cara melibatkan siswa secara aktif dalam proses pembelajarannya.

Peneliti mencoba merancang pembelajaran dengan menerapkan model pembelajaran creative problem solving (CPS) untuk membantu siswa dalam memahami materi peristiwa alam. Model pembelajaran creative problem solving (CPS) merupakan suatu model yang menekankan pada kerja kelompok yang memusatkan pada pembelajaran dan keterampilan pemecahan masalah yang diikuti dengan kekuatan keterampilan (Uno et al, 2011: 223). Model pembelajaran creative problem solving (CPS) dapat dijadikan sebagai model pembelajaran yang menyenangkan bagi siswa. Siswa akan cenderung tertantang mengikuti proses pembelajaran, karena model ini dapat membiasakan siswa menghadapi dan memecahkan masalah secara terampil, dan merangsang pengembangan kemampuan berpikir siswa secara kreatif dan menyeluruh melalui berbagai kegiatan. Keefektifan penerapan model pembelajaran creative problem solving (CPS) dapat dilihat dari beberapa hasil penelitian berikut diantaranya dilakukan oleh Ciptaningtyas (2016) bahwa model creative problem solving (CPS) efektif meningkatkan hasil belajar siswa. Hal ini terlihat dari hasil belajar siswa mencapai ketuntasan secara klasikal sebesar 97,44\%. Penelitian Oktaviani\&Nugroho (2015) menunjukan bahwa model pembelajaran creative problem solving (CPS) dapat meningkatkan pemahaman konsep dan keterampilan berkomunikasi. Penelitian Subakir (2013) menjelaskan bahwa model pembelajaran creative problem solving (CPS) 
dapat meningkatkan kemampuan berfikir kreatif dan hasil belajar siswa. Selanjutnya penelitian Hikmah, D.,\&M. Natsir. (2009) menyatakan bahwa penerapan pembelajaran creative problem solving (CPS) dapat meningkatkan hasil belajar fisika dan aktivitas belajar siswa. Membiasakan siswa dalam mencari sendiri jawaban dari permasalahan yang dimunculkan dapat meningkatkan pemahaman konsep dan keterampilan komunikasi siswa dalam pembelajaran fisika. Triyono, dkk (2017) hasil penelitian menunjukkan adanya pengaruh yang positif pembelajaran Ilmu Pengetahuan Alam berbasis creative problem solving (CPS) terhadap kemampuan kreativitas siswa.

1. Model pembelajaran creative problem solving (CPS)

Model pembelajaran creative problem solving merupakan variasi dari pembelajaran pemecahan masalah. Menurut Osborn (dalam Huda, 2014: 298) mengemukakan bahwa 'creative problem solving (CPS) merupakan model pembelajaran yang digunakan untuk menyelesaikan masalah secara kreatif'. Jadi pembelajaran ini merupakan pembelajaran berbasis masalah yang berpusat pada keterampilan pemecahan masalah yang dilakukan oleh siswa. Guru dalam model Creative Problem Solving (CPS) bertugas untuk mengarahkan upaya pemecahan masalah secara keatif yang dilakukan oleh siswa. Guru menyediakan materi pelajaran atau topik diskusi yang dapat merangsang siswa untuk berpikir kreatif dalam memecahkan masalah. Melalui berpikir kreatif siswa tidak hanya menerima pengetahuan dari guru, namun siswa juga berusaha mencari tahu pengetahuannya sendiri dalam proses pembelajaran. Pembelajaran dengan model creative problem solving membiasakan siswa untuk mengembangkan proses berpikir kreatif dalam menyelesaikan suatu masalah dengan langkah-langkah yang terstruktur, sehingga siswa lebih memahami konsep serta mampu mengkomunikasikan pemikirannya. Selanjutnya Baer (Triyono, dkk, 2017) menyebutkan bahwa creative problem solving merupakan salah satu model yang dipandang efektif dan dapat membantu pemecahan berbagai masalah dalam kehidupan seharihari.
Menurut Osborn (dalam Huda, 2014: 298) mengemukakan langkah-langkah model pembelajaran creative problem solving (CPS) yaitu sebagai berikut:

a. Objective Finding

Siswa dibagi ke dalam kelompokkelompok. Siswa mendiskusikan situasi permasalahan yang diajukan guru dan membrainstroming sejumlah tujuan atau sasaran yang bisa digunakan untuk kerja kreatif mereka.

b. Fact Finding

Siswa membrainstroming semua fakta yang mungkin berkaitan dengan sasaran tersebut.

\section{c. Problem Finding}

Salah satu aspek terpenting dari kreativitas adalah mendefinisikan kembali perihal permasalahan agar siswa bisa lebih dekat dengan masalah sehingga memungkinkannya untuk menemukan solusi yang lebih jelas.

\section{d. Idea Finding}

Gagasan-gagasan siswa didaftar agar bisa melihat kemungkinan menjadi solusi atas situasi permasalahan.

\section{e. Solution Finding}

Gagasan-gagasan yang memiliki potensi terbesar dievaluasi bersama sehingga menjadi solusi untuk memecahkan permasalahan.

f. Acceptance Finding

Siswa mulai mempertimbangkan isu-isu nyata dengan cara berpikir yang sudah mulai berubah. Siswa diharapkan sudah memiliki cara baru untuk menyelesaikan berbagai masalah secara kreatif.

Dari penjelasan langkah-langkah model pembelajaran creative problem solving (CPS) di atas, siswa dilatih untuk dapat berpikir sistematis dan logis, berpikir kritis dalam memecahkan permasalahan, mengkomunikasikan berbagai ide, dan melatih siswa untuk saling berinteraksi satu sama lain melalui kegiatan kelompok. Hasil beberapa penelitian menunjukan bahwa model creative problem solving (CPS) juga dapat meningkatkan kemampuan berpikir secara kritis dan kreatif dalam menyelesaikan masalah yang dihadapi, dengan meningkatnya kemampuan berpikir kritis dan kreatif terhadap permasalahan yang dipelajari memungkinkan siswa dapat lebih mudah dalam menyelesaikan permasalahan sehingga dapat mempengaruhi hasil belajarnya. Hal ini 
sesuai dengan hasil Penelitian Eriyanti, E. \& Suryanti (2018) bahwa pembelajaran menggunakan model pembelajran creative problem solving (CPS) berpengaruh positif terhadap kemampuan berpikir kritis siswa kelas IV SDN Kemuning Tarik Sidoarjo yang dibuktikan dengan hasil uji $t$ test menunjukkan perbedaan yang signifikan. Selanjutnya penelitian Busyari, A. \& Sinaga, P. (2015) menjelaskan bahwa penerapan pembelajaran creative problem solving (CPS) berbasis eksperimen secara signifikan dapat lebih meningkatkan kemampuan kognitif dan keterampilan berpikir kreatif dalam pemecahan masalah siswa dibanding penerapan pembelajaran konvensional.

Kelebihan model pembelajaran creative problem solving (CPS) menurut Huda (2014: 320) yaitu sebagai berikut:

a. Memberi kesempatan kepada siswa untuk memahami konsep-konsep dengan cara menyelesaikan suatu permasalahan.

b. Membuat siswa aktif dalam pembelajaran.

c. Mengembangkan kemampuan berpikir siswa karena disajikan masalah pada awal pembelajaran dan memberi keleluasaan kepada siswa untuk mencari arah-arah penyelesaiannya.

d. Membuat siswa dapat menerapkan pengetahuan yang sudah dimilikinya ke dalam situasi baru.

Berdasarkan pemaparan di atas dapat disimpulkan bahwa kelebihan dari model pembelajaran creative problem solving (CPS) yaitu siswa lebih aktif dalam pembelajaran karena siswa yang mencari tahu sendiri pengetahuannya berdasarkan pengalaman yang dijumpai, melatih siswa untuk berpikir kreatif dan kritis dalam memecahkan permasalahan, kegiatan pembelajaran lebih menarik karena tidak terikat di dalam kelas, interaksi antar siswa lebih banyak karena hampir setiap langkah pemecahan masalah didiskusikan secara berkelompok dan siswa mampu mengaplikasikan pengetahuan yang dimilikinya ke dalam situasi yang nyata.

Penerapan model creative problem solving (CPS) diharapkan dapat berpengaruh terhadap hasil belajar siswa dan menambah kreativitas siswa dalam proses pembelajaran. Dengan membiasakan siswa memecahakan masalah secara kreatif diharapkan dapat membantu siswa mengatasi berbagai kesulitan yang berkaitan dengan ilmu pengetahuan alam yang tentunya dalam menyelesaikannya memerlukan keterampilan berpikir kreatif.

2. Hasil Belajar

Belajar merupakan suatu proses dimana terjadinya perubahan tingkah laku dalam diri seseorang baik dari segi pengetahuan maupun mental. Menurut Sudjana (2016: 22), hasil belajar adalah kemampuan-kemampuan yang dimiliki siswa setelah menerima pengalaman belajarnya. Hasil belajar merupakan kemampuan yang diperoleh setelah kegiatan belajar, sehingga dapat merubah tingkah laku yang dimiliki seseorang. Berdasarkan pemaparan tersebut dapat disimpulkan bahwa hasil belajar merupakan kemampuan yang dimiliki siswa setelah melakukan proses pembelajaran dan dari pengalaman belajarnya sehingga adanya perubahan tingkah laku seseorang baik dari segi ranah kognitif, afektif, maupun psikomotoriknya.

Terdapat beberapa faktor yang mempengaruhi hasil belajar siswa. Faktor utama berasal dari dalam diri siswa itu sendiri. Setiap siswa diyakini memiliki kemampuan serta bakat yang berbeda-beda, atas dasar itu pula mengapa hasil belajar yang dicapai siswa akan berbeda. Selain itu faktor lingkungan sangat mempengaruhi hasil belajar siswa karena sehebat apapun hasil belajar siswa ketika berada dalam lingkungan yang tidak kondusif maka akan berpengaruh terhadap hasil belajarnya. Adapun faktor berikutnya yang akan berpengaruh terhadap hasil belajar siswa adalah sarana dan prasarana yang menunjang pembelajaran itu sendiri, perencanaan pelaksanaan pembelajaran yang kurang maksimal serta tidak didukung media pembelajaran yang sesuai maka berpengaruh pada hasil belajar siswa. Dengan demikian dalam merancang pembelajaran guru sudah sangat selayaknya mempersiapkan pembelajaran dengan baik, yaitu dengan memilih strategi atau model pembelajaran yang tepat dan inovatif.

\section{Metode Penelitian}

Penelitian ini menggunakan metode penelitian tindakan kelas. Penelitian tindakan kelas merupakan ragam penelitian pembelajaran yang berkonteks kelas, dilaksanakan oleh guru untuk memecahkan masalah-masalah pembelajaran, memperbaiki mutu dan hasil pembelajaran, dan mencobakan hal-hal baru dalam pembelajaran 
untuk peningkatan mutu dan hasil belajar (Dasna, 2008: 25). Adapun tempat penelitian yaitu di SDN Karamat I Kecamatan Palasah Kabupaten Majalengka dengan subjek penelitiannya yaitu siswa siswi kelas $\mathrm{V}$ yang berjumlah 20 orang. Pengambilan data dilakukan melalui kegiatan observasi, wawancara, dokumentasi, dan tes hasil belajar siswa. Adapun teknik analisis data dilakukan melalui reduksi data, tabulasi data hasil observasi, analisi data dan pemaparan data. Kriteria keberhasilan dalam penelitian ini yaitu jika nilai hasil belajar Ilmu Pengetahuan Alam siswa mencapai minimal $85 \%$ atau 17 orang dari kriteria ketuntasan minimum. Model penelitian tindakan kelas yang digunakan adalah model John Elliot seperti pada gambar 1 yang mana langkah penelitian pada setiap siklusnya meliputi empat tahapan, yaitu: perencanaan, tindakan, observasi, dan refleksi dalam satu siklus.

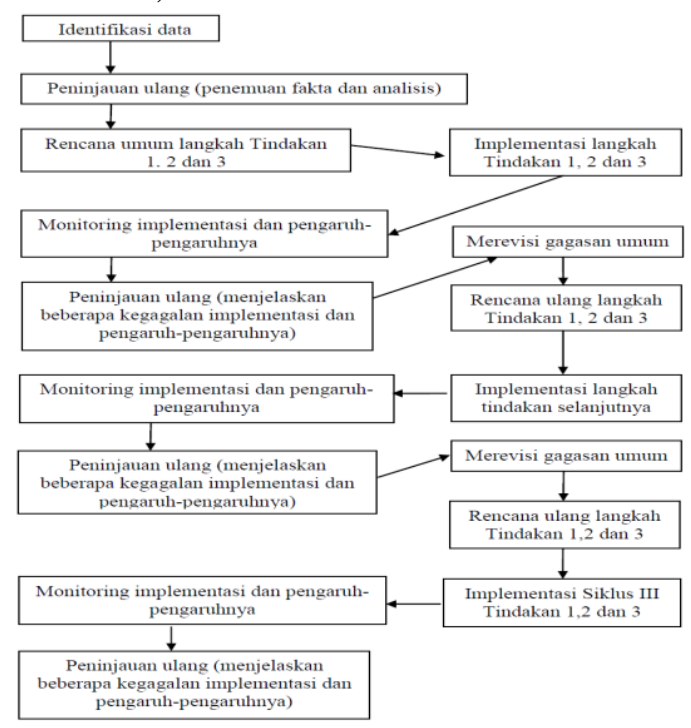

Gambar 1. Model John Elliott

\section{Hasil dan Pembahasan}

Berdasarkan hasil penelitian pada siklus I tindakan I, II dan III maka diperoleh nilai pada siklus I siswa yang tuntas sebanyak 8 siswa (40\%) dan yang belum tuntas 12 siswa $(60 \%)$ dari jumlah siswa 20 orang. Hasil belajar di siklus I nilai tertinggi diperoleh oleh satu orang siswa dengan nilai 85 dan terendahnya diperoleh oleh satu orang dengan nilai 30. Sedangkan nilai rata-rata yang diperoleh siswa kelas V SDN Karamat 1 adalah 65,08 .
Berdasarkan hasil penelitian pada siklus II tindakan I, II dan III maka diperoleh nilai siswa yang tuntas sebanyak 11 siswa (55\%) dan yang belum tuntas 9 siswa (45\%) dari jumlah siswa 20 orang. Hal ini menunjukan bahwa hasil belajar siswa kelas $\mathrm{V}$ sudah terlihat adanya peningkatan dari siklus I siswa ke siklus II. Hasil belajar siklus II nilai tertinggi didapat oleh satu orang siswa dengan nilai 90 dan nilai terendah didapat oleh satu orang siswa dengan nilai 25 , sedangkan nilai yang diperoleh siswa kelas $\mathrm{V}$ SDN Karamat adalah 66,50. Pada siklus II terlihat adanya peningkatan yaitu $15 \%$.

Pada hasil evaluasi siklus III didapat bahwa 17 siswa (85\%) yang sudah tuntas dan 3 siswa (15\%) yang belum tuntas dari jumlah siswa 20 orang. Hal ini menunjukan bahwa hasil belajar siswa kelas $\mathrm{V}$ sudah terlihat adanya peningkatan yang signifikan dari siklus II ke siklus III, dimana siklus II siswa yang tuntas hanya berjumlah 11 siswa (55\%) yang tuntas dan tidak tuntas 9 siswa (45\%) yang belum tuntas. Hasil belajar di siklus III nilai tertinggi diperoleh dengan nilai 100 dan terendah dengan nilai 75 , sedangkan nilai rata-rata yang diperoleh siswa kelas V SDN Karamat adalah 80,00. Pada siklus III terlihat adanya peningkatan sekitar $30 \%$.

Berdasarkan hasil pengamatan dalam pembelajaran dengan menerapkan model creative problem solving terdapat peningkatan hasil belajar tiap siklusnya, yaitu sebagai berikut:

Tabel 1. Rekap Peningkatan Ketuntasan Hasil Belajar

\begin{tabular}{llccc}
\hline No & Tingk. & $\begin{array}{c}\text { Siklus I } \\
(\text { siswa / } \\
\text { persentase) }\end{array}$ & $\begin{array}{c}\text { Siklus II } \\
(\text { siswa / } \\
\text { persentase) }\end{array}$ & $\begin{array}{c}\text { Siklus III } \\
\text { (siswa / } \\
\text { persentase) }\end{array}$ \\
\hline 1 & Tuntas & $8 /(40 \%)$ & $11 /(55 \%)$ & $17 /(85 \%)$ \\
\hline 2 & $\begin{array}{l}\text { Belum } \\
\text { tuntas }\end{array}$ & $12 /(60 \%)$ & $9 /(45 \%)$ & $3 /(15 \%)$ \\
\hline & Total & $20 /(100 \%)$ & $20 /(100 \%)$ & $20 /(100 \%)$ \\
\hline
\end{tabular}

Berdasarkan tabel di atas dapat dilihat bahwa hasil belajar siswa pada setiap siklus cenderung meningkat. Data hasil penelitian yang didapat selain terjadi peningkatan jumlah siswa yang tuntas juga disertai dengan 
peningkatan rata-rata kelas, berikut merupakan grafik peningkatan nilai rata-rata kelas pada tiap siklusnya:

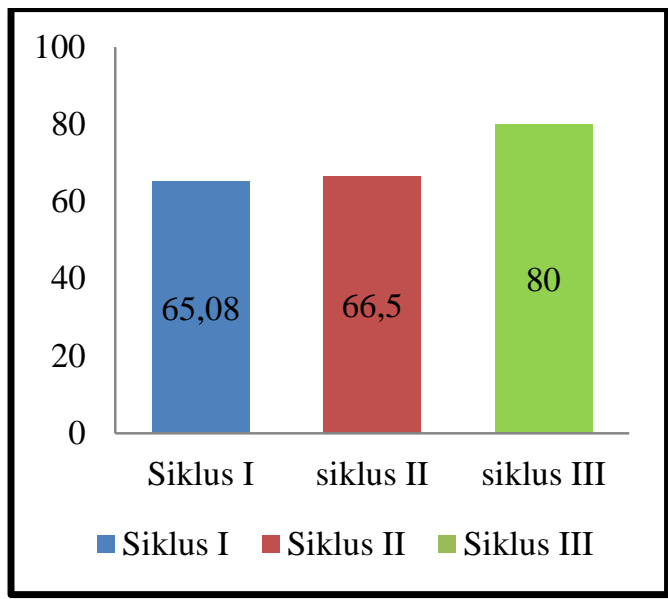

Gambar 2. Rata-rata Kelas pada tiap Siklus

Berdasarkan diagram di atas dapat dilihat bahwa rata-rata nilai siswa pada pembelajaran Ilmu Pengetahuan Alam pada siklus I, II dan III mengalami peningkatan. Pada siklus I nilai rata-rata kelas mencapai 65,08 , siklus II nilai rata-rata kelas 66,50, dan siklus III yaitu mencapai 80,0.

Berdasarkan data hasil penelitian yang tergambar pada gambar 1 dan 2, dapat terlihat bahwa peningkatan hasil belajar secara signifikan terjadi dari siklus II ke siklus III hal ini ditunjukan dengan persentase jumlah siswa yang tuntas maupun rata-rata kelas meningkat secara signifikan. Peningkatan tersebut tidak terlepas dari upaya peneliti memperbaiki proses pembelajaran pada setiap siklusnya salah satunya yaitu dengan cara memvariasikan beberapa kegiatan dan media pembelajaran.

Peningkatan jumlah siswa tuntas maupun rata-rata kelas pada siklus I belum terjadi secara signifikan dikarenakan pelaksanaan pembelajaran dengan menerapkan model creative problem solving (CPS) belum optimal, masih terdapat siswa yang sulit untuk dikondisikan selain itu juga ditemukan permasalahan lain yaitu pada kegiatan diskusi kelompok sebagian siswa masih belum sepenuhnya mengerti aturan diskusi dan masih kebingungan dalam merumuskan alternatif pemecahan masalah, namun dalam kegiatan percobaan siswa terlihat sangat antusias. Selanjutnya peneliti berupaya memperbaiki proses pembelajaran sehingga proses pembelajaran pada siklus II sudah berjalan lebih baik dari siklus sebelumnya dimana langkah-langkah pembelajaran sudah terimplementasi sesuai dengan sintaks model dan permasalahan pembelajaran yang muncul pada siklus I sudah dapat teratasi. Hal ini terlihat dari siswa yang sudah bisa dikondisikan dengan baik pada saat akan memulai pembelajaran, sebagian siswa sudah mulai berani dalam mengemukakan pendapatnya dan terlibat aktif dalam kegiatan tanya jawab, antusias dan saling kerjasama dalam kegiatan percobaan, mampu mengamati dan menuliskan hasil pengamatan dengan baik, siswa juga sudah mulai berani dalam mempresentasikan hasil diskusi dan mengomentari hasil kelompok lain. Selanjutnya siswa sudah mulai bisa merumuskan beberapa alternatif pemecahan masalah, serta menentukan salah satu alternatif yang didapat sebagai salah satu solusi dalam memecahkan permasalahan tersebut. Model pembelajaran creative problem solving (CPS) menekankan pada kreativitas dalam memecahkan masalah. Siswa dituntut aktif sehingga dalam pembelajaran siswa mampu mengeluarkan kemampuan yang dimiliki untuk memecahkan masalah yang belum pernah mereka temui (Triyono, $d k k$. 2017).

Pada siklus III, proses pembelajaran sudah berjalan lebih baik lagi dari siklus II. Hal ini terlihat dari siswa yang sudah berani mengemukakan pendapat dan terlibat aktif dalam kegiatan tanya jawab dengan tidak malu-malu lagi untuk menjawab pertanyaan bahkan mengajukan pertanyaan kepada guru. Melalui pembelajaran creative problem solving (CPS), siswa mengkonstruksi makna atau pengertian berdasarkan pengetahuan awal yang dimiliki, mengintegrasikan pengetahuan yang baru kedalam skema yang telah ada dalam pemikiran siswa sendiri. Salah satu kegiatan pengkonstruksian pengetahuan yang dilakukan siswa yaitu melalui kegiatan tanya jawab. Kegiatan tanya jawab dalam proses pembelajaran creative problem solving (CPS) dapat berdampak positif pada proses dan hasil belajar siswa hal ini sesuai dengan pendapat Sanjaya (2016: 34) bahwa pertanyaan yang baik memiliki dampak yang positif terhadap siswa salah satunya yaitu "dapat meningkatkan kemampuan berpikir siswa, sebab berpikir itu sendiri pada hakikatnya adalah bertanya". Pada saat kegiatan diskusi berlangsung siswa 
sudah terlibat aktif dalam kegiatan diskusi dan saling menghargai pendapat orang lain sehingga hubungan antara siswa dengan siswa sudah terjalin sangat baik dan menumbuhkan partisipasi yang positif dalam proses pembelajaran. Selanjutnya hasil penelitian pada siklus III ini menunjukan bahwa siswa sudah memiliki rasa ingin tahu yang tinggi dalam kegiatan percobaan, terampil dalam melakukan percobaan dan mampu menuliskan hasil pecobaan dengan tepat, saling kerjasama dan tanggung jawab dalam menyelesaikan permasalahan yang ada, siswa bisa merumuskan beberapa alternatif yang akan dijadikan sebagai bahan untuk meyelesaikan permasalahan yang ditemui, serta mampu menentukan dengan baik salah satu alternatif yang akan dijadikan sebagai solusi dalam memecahkan permasalahan, selain itu siswa juga antusias dan percaya diri dalam mempresentasikan hasil diskusi dan mengomentari hasil dari kelompok lain.

Berdasarkan penjelasan di atas dapat disimpulkan bahwa penerapan model pembelajaran creative problem solving (CPS) terbukti dapat meningkatkan hasil belajar siswa kelas V SDN Karamat I pada pembelajaran Ilmu Pengetahuan Alam. Peningkatan hasil belajar yang diperoleh tersebut tidak terlepas dari berbagai kegiatan pada model pembelajaran creative problem solving (CPS) yang berdampak positif pada peningkatan hasil belajar siswa, hal ini sesuai dengan penjelasan Pepkin (dalam Oktaviani\&Nugroho, 2015) bahwa model creative problem solving (CPS) digunakan pemusatan pada pengajaran dan keterampilan pemecahan masalah, yang diikuti dengan penguatan keterampilan. Ketika siswa dihadapkan pada suatu permasalahan maka siswa dapat melakukan keterampilan memecahkan masalah untuk memilih dan mengembangkan ide serta pemikirannya, tidak hanya menggunakan cara menghafal tanpa proses berpikir, tetapi menggunakan keterampilan memecahkan masalah yang mengembangkan proses berpikir. Dengan demikian seiring dengan meningkatknya kemampuan berpikir dan keterampilan memecahkan masalah maka disertai dengan meningkatnya hasil belajar siswa.

\section{Kesimpulan}

Berdasarkan hasil penelitian yang telah dipaparkan, dapat disimpulkan bahwa model pembelajaran creative problem solving (CPS) dapat meningkatkan hasil belajar siswa pada pembelajaran Ilmu Pengetahuan alam di kelas V Sekolah Dasar. Peningkatan nilai hasil belajar tersebut dipengaruhi oleh aktivitas siswa selama proses pembelajaran di dalam kelas. Model pembelajaran creative problem solving (CPS) memberikan dampak yang positif pada aktivitas dan kemampuan berpikir siswa dalam memecahkan permasalahan secara kreatif.

\section{Daftar Pustaka}

Busyari, A. \& Sinaga, P. (2015). Strategi pembelajaran creative problem solving (CPS) berbasis eksperimen untuk meningkatkan kemampuan kognitif dan keterampilan berpikir kreatif. Jurnal pengajaran MIPA. 20(2), hlm 133-143.

Ciptaningtyas, A. (2016). Penerapan Model Pembelajaran Kooperatif Metode Creative Problem Solving (CPS) Pada Materi Bilangan di SMP Kelas VII. Jurnal ilmiah pendidikan matematika. 5(1), hlm 1-5.

Eriyanti, E. \& Suryanti. (2018). Pengaruh model creative problem solving (CPS) terhadap kemampuan berpikir kritis pada pembelajaran IPA Kelas IV SDN Kemuning Tarik Sidoarjo. Jurnal Penelitian Pendidikan Guru Sekolah Dasar. 6(9), hlm. 1548-1557.

Hamdu, G \& Agustina, L. (2011). Pengaruh motivasi belajar siswa terhadap prestasi belajar IPA di sekolah dasar. Jurnal penelitian pendidikan. 12(1), hlm 81-86.

Hikmah, D., \& M. Natsir. (2009). Penerapan Pembelajaran Berbasis Masalah Tipe Creative Problem Solving (CPS) untuk Meningkatkan Ketuntasan Belajar Fisika Siswa Kelas VIII-E SMP N 1 Ma'rang Kabupaten Pangkep. JSP. 10, hlm1-9.

Huda, M. (2014). Model-Model Pengajaran dan Pembelajaran. Yogyakarta: Pustaka Pelajar. 
Oktaviani\&Nugroho. (2015). Penerapan model model pembelajaran creative problem solving (CPS) pada pembelajaran kalor untuk meningkatkan pemahaman konsep dan keterampilan komunikasi. Unnes Physics Education Journal. 4(1), hlm 27-31.

Prastiwi, M. (2018). Kemampuan pemecahan masalah pada siswa kelas VII SMP. Ejurnal-pensa. 6(2), hlm 98-103.

Subakir, B. (2013). Peningkatan Belajar Kreatif dan Hasil Belajar Fisika Melalui Pendekatan Creative Problem Solving (CPS). Jurnal pendidikan fisika. 2(2), hlm 49-56.

Sanjaya, W. (2016). Strategi Pembelajaran: Berorientasi Standar Proses Pendidikan. Jakarta: Kencana.

Susanto, A. (2014). Teori Belajar dan Pembelajaran di Sekolah Dasar. Jakarta: Kencana.

Triyono, dkk. (2017). Pengaruh pembelajaran ipa berbasis creative problem solving terhadap kreativitas siswa SMP. Jurnal Pendidikan. 1(2), hlm 214-226.

Uno, Hamzah, B. dan Nurdin, M. (2011). Belajar dengan Pendekatan PAIKEM. Jakarta: Bumi Aksara.

Yuliati, Y. (2016). Peningkatan Keterampilan Berpikir Kreatif Siswa Sekolah Dasar Melalui Model Pembelajaran Berbasis Masalah. Prosiding seminar nasional pendidikan dasar. Vol 2, hlm 124-129. 